\title{
Plasma levels of various amino acids and their changes upon protein uptakes in Japanese young and old men and women
}

\author{
Shimizu $F^{1}$, Ishii $Y^{1}$, Ogawa $M^{1}$, Takao $T^{1}$, Matsuoka $K^{2}$, Kato $K^{2}$ and Takada $A^{3}$ \\ ${ }^{1}$ Faculty of Human Life and Environmental Sciences, Showa Women's University, Tokyo, Japan \\ ${ }^{2}$ Medical Services, Saiseikai Shibuya Clinic, Tokyo, Japan \\ ${ }^{3}$ International Projects on Food and Health(NPO), Tokyo, Japan
}

\begin{abstract}
Background: It is not known whether plasma amino acids levels are different between young and old men and women in Japan. No studies have been reported whether protein uptakes influence plasma levels of amino acids, lipids, insulin and glucose.

Methods: Self-administered diet history questionnaires were given to young, old men and women. Bood samples were taken early morning to determine plasma levels of various factors.

Results: Women and old people had lower plasma levels of most of amino acids, especially essential and branched-chain amino acids than men and young people. The uptakes of total, animal or vegetable proteins did not affect plasma levels of total amino acids. The uptakes of total protein did not affect plasma levels of lipids (triglycerides (TG), or LDL cholesterol) except for young men and old women whose plasma levels of HDL-cholesterol increased upon the uptake of total protein. Plasma levels of BCAAs did not affect plasma levels of insulin, glucose, or lipids. Increase in plasma BCAAs levels results in increase in plasma insulin levels.

Conclusion: old people or women have lower plasma levels of essential amino acids and BCAAs than young people or women, respectively. Increase in plasma levels of BCAAs increased only plasma levels of insulin, no increase being shown in plasma levels of glucose, TG, HDL-and LDL-cholesterol. In healthy men and women, the metabolisms of BCAAs and their effects on glucose homeostasis are not impaired.
\end{abstract}

Abbreviations: AAs: Amino acids; BCAAs: Branched-chain amino acids; TG: Triglycerides: HDL: High-density lipoprotein; LDL: Lowdensity lipoprotein

\section{Introduction}

Amino acids are important factors involved in the metabolism of proteins in all the tissues. A number of studies have indicated that branched -chain amino acids (BCAAs) such as leucine, isoleucine and valine are important in the regulation of protein synthesis [1]. Unlike other essential amino acids, BCAAs are degraded in skeletal muscle, and their circulating levels are higher postprandially [2], thus may influence glucose homeostasis. Branched-chain amino acids concentrations have been shown to be elevated in response to overnutrition and can affect insulin sensitivity and secretion [3]. Number of human studies have consistently indicated that concentrations of BCAAs in plasma and urine are associated with insulin resistance [4-7]. We recently examined relationship between various foods uptakes and body mass index (BMI) and various plasma parameters in Japanese young and old men and women [8]. We now report plasma levels of amino acids and their changes upon protein uptakes in young and old men and women in Japan.

\section{Ethics}

This work has been approved by the Ethical committees of Showa Women's University and NPO "International projects on food and health" and has been carried out in accordance with The Code of
Ethics of the World Medical Association (Declaration of Helsinki) for experiments.

\section{Methods}

We asked men and women older than 50 years old and men and women college students to participate in the experiments. checked their health carefully and recruited them if there were no health problems such as diabetes, hypertension nor serious diseases experienced in the past. They did not smoke in the past. We also excluded people who took drugs for dyslipidemia, hyperglycemia, or hypertension.

Participants were asked not to eat anything after 21.00 PM the previous evening. We took blood samples between 9.00 AM and 11.00 AM. Plasma specimens were collected for assays of blood parameters. We obtained an informed consent prior to conducting the protocol which had been approved by the Ethical Committee of Showa Women's University and Saiseikai Shibuya Satellite Clinic.

Correspondence to: Takada A, International Projects on Food and Health (NPO), Sumida-ku Ishiwara 1-30-6-802, Tokyo 130-0011, Japan, Tel: 81338291849; Fax: 81338291847; E-mail: takadaa@mwd.biglobe.ne.jp

Key words: amino acids, essential amino acids, branched-chain amino acids (BCAAs). protein, insulin, glucose, HDL, LDL-cholesterol

Received: October 05, 2017; Accepted: October 31, 2017; Published: November 03,2017 
Self-administered diet history questionnaires were given to healthy volunteers and were asked to describe answers on each item by recollection of diets they took. From these questionnaires, we calculated the intakes of energy, carbohydrate, fat, and protein.

After plasma was separated from blood, plasma factors were measured. Ethylenediamine tetra acetic acid (EDTA) was used as an anticoagulant. Blood glucose levels were measured by a hexokinase UV method. The CLEIA (chemiluminescent immunoassay) method was used foe the measurement of insulin.

The thawed samples were deproteinized with acetonitrile followed by the amino acid analysis. Pre-column derivatization in the UFAmino Station was automatically performed using an automated sample injector with the regent APDSTAG (Wako Pure Chemical Industries, Ltd., Osaka Japan). Target free amino acids as derivatized compounds were separated under a reversed phase UHPLC condition and determined by the liquid chromatograph mass spectrometer.

Lipid and lipoprotein concentrations (total cholesterol, HDL, TG) were determined using a Polychem Chemistry Analyzer (Polymedco Inc.). FFA concentrations were measured by a gas chromatography.

\section{Statistics}

The results are presented as means \pm SEM. Statistical significance of the differences between groups was calculated according to one-way ANOVA. When ANOVA indicated a significant difference $(\mathrm{P}<0.05)$, the mean values of the treatment were compared using Tukey's least significant difference test at $\mathrm{P}<0.05$. Spearman's correlation tests were used to examine statistical significance.

\section{Results}

Table 1 shows the background of participants. We here just mention about ages, heights and body weights because the other parameters were indicated the previous paper [8].

Table 2 shows plasma levels of amino acids, essential, non-essential, and branched chain amino acids of young and old Japanese men and women. We here just pay attention to plasma levels of branched-chain amino acids (BCAAs) such as leucine, isoleucine and valine since their plasma levels are implicated to closely associated with diabetes mellitus. Table 2 shows that the plasma levels of BRAAs are lower in women that in men and lower in older people than younger people. Same relationships hold for essential amino acids (EAAs) such as BCAAS, tryptophan, histidine, phenylalanine, lysine, methionine, and threonine.

Table 3 shows that only in young men, the uptakes of meat and egg protein resulted in significant decrease in total plasma amino acids levels.

Total protein uptakes had nothing to do with plasma levels of glucose, insulin, TG, and LDL-cholesterol. In young men and old women, total protein uptakes resulted in crease in plasma levels of HDL-cholesterol (Table 4).

The data indicate that plasma insulin levels increase with increase in plasma BCAAs levels, most significantly in young men (Table 5).

\section{Discussion}

Protein uptakes not only influence the body growth but the development of the brain. In 1960s, families with young children were given nutritional supplement in rural Guatemala [9]. A team tested the assumption that giving enough protein in the first few years of life would decrease the incidence of stunted growth. Children who got protein supplements grew 1-2 centimeters taller than a control group. They also found that children who received the protein supplements scored better on reading and knowledge tests as adolescents. These results indicate that protein uptakes are important for the normal development of the body and the brain and intelligence.

Recently, much attention has paid to gender and age differences of diagnoses and treatments of various diseases [10]. In fact, the vast majority of animal studies have been conducted on males, mostly in rodents. For example, the number one killer of US women is heart disease, far exceeding death from breast cancer, Old women and men have a blockade of one or more of coronary arteries, young women are more likely to have diffuse plaques that line and narrow the entire artery [10].

So we thought it is vitally important to examine data using different age and gender groups. So far we examined various foods uptakes in young and old men and women in Japan [8]. We asked young college students and old male and female acquaintances to participate in the study. The number of participants of 4 groups and their ages, heights and weights are shown in Table 1.

There are some papers indicating that insulin regulates the metabolism of carbohydrate, lipid, protein, and amino acid [11]. Proteolysis and associated release of amino acids are inhibited by insulin and insulin stimulates amino acid uptake and protein synthesis in skeletal muscle $[12,13]$. High insulin levels were shown to stimulate skeletal muscle protein synthesis [14]. As to individual amino acids, the plasma levels of alanine, phenylalanine, valine, leucine, isoleucine, and tyrosine were shown to increase and the plasma levels of histidine and glutamine were shown to decrease in hyperglycemia [15].

There has been no research investigation concerning the effects of glucose or sucrose administration on plasma levels of various amino acids in young and aged male adults.

Fernstrom, J.D. and Wurtman, R.J. indicated that when plasma tryptophan concentrations were raised by receiving tryptophan in foods [16] or injection of insulin [17], the brain serotonin and tryptophan concentration increased. They indicated that carbohydrate ingestion increased insulin secretion which raised plasma tryptophan and lowered the concentration of the competing amino acids such as branched neutral amino acids in rats [18]. Carbohydrate ingestion was shown to decrease plasma free amino acid levels [19], and glucose intake resulted in a decrease in large neutral amino acids such as methionine, phenylalanine, tyrosine, and tryptophan [20]. These results suggested that an increase in plasma levels of glucose or insulin may increase the transport of some amino acids using various transporters, thus decreasing the concentration of such amino acids.

We reported that the plasma levels of EAAs, such as phenylalanine, leucine, isoleucine, valine, and tryptophan, decreased after the administration of glucose in humans [21]. We also found that both EAA and BCAA levels after sucrose administration significantly decreased in both young and aged men. Probably changes in the plasma levels of EAAs and BCAAs are sensitive to an increase in the insulin levels because sucrose administration resulted in lower levels of insulin than glucose administration.

These results suggest that there were significant decreases in the plasma levels of total amino acids, EAAs, and NEAAs after glucose administration in both old and young men. 
Table 1. The background parameters of participants

\begin{tabular}{|c|c|c|c|c|c|}
\hline & $\mathbf{a}$ & b & c & d & \multirow{2}{*}{ Statistical Significances } \\
\hline & Young men $(\mathrm{n}=49)$ & Young women $(\mathrm{n}=47)$ & Old men $(n=25)$ & Old women $(n=39)$ & \\
\hline Age & $20.7 \pm 1.5$ & $21.2 \pm 0.7$ & $60.8 \pm 9.9$ & $67.4 \pm 7.5$ & $\begin{array}{l}\text { a vs. c; } \mathrm{p}<0.01, \text { a vs. } \mathrm{d} ; \mathrm{p}<0.01 \\
\text { b vs. c; } \mathrm{p}<0.01, \mathrm{~b} \text { vs. } \mathrm{d} ; \mathrm{p}<0.01 \\
\text { c vs. } \mathrm{d} ; \mathrm{p}<0.01\end{array}$ \\
\hline Height (m) & $1.72 \pm 0.06$ & $1.58 \pm 0.05$ & $1.69 \pm 0.07$ & $1.57 \pm 0.06$ & $\begin{array}{l}\text { a } v s . \mathrm{b} ; \mathrm{p}<0.01, \text { a } v s . \mathrm{d} ; \mathrm{p}<0.01 \\
\text { b vs. c; } \mathrm{p}<0.01, \mathrm{c} v s . \mathrm{d} ; \mathrm{p}<0.01\end{array}$ \\
\hline Weight (kg) & $65.1 \pm 8.9$ & $51.4 \pm 5.8$ & $71.1 \pm 13.1$ & $50.6 \pm 6.8$ & $\begin{array}{l}\text { a } v s . \mathrm{b} ; \mathrm{p}<0.01, \text { a } v s . \mathrm{d} ; \mathrm{p}<0.01 \\
\text { b vs. c; } \mathrm{p}<0.01, \mathrm{c} v s . \mathrm{d} ; \mathrm{p}<0.01\end{array}$ \\
\hline
\end{tabular}

a,b,c,d indicate plasma values of ages, heights and weights of participants, respectively.

Table 2. Various amino acids levels in plasma20 in Japanese young and old men and women

\begin{tabular}{|c|c|c|c|c|c|}
\hline \multirow{2}{*}{$\begin{array}{l}\text { Amino acid } \\
\text { Histidine }\end{array}$} & \multicolumn{4}{|c|}{ Plasma amino acids levels of 12 young and old men and women } & \multirow{2}{*}{$\begin{array}{l}\text { Statistical significance } \\
\text { a } v s . \mathrm{d} ; \mathrm{p}<0.01, \mathrm{c} v s . \mathrm{d} ; \mathrm{p}<0.01\end{array}$} \\
\hline & $78.5 \pm 7.7$ & $74.1 \pm 6.0$ & $78.7 \pm 7.5$ & $72.2 \pm 6.6$ & \\
\hline Lysine & $185.9 \pm 28.6$ & $154.0 \pm 23.7$ & $190.9 \pm 28.7$ & $170.0 \pm 20.4$ & $\begin{array}{l}\text { a vs. b; } ;<0.01, \text { a } v s . \mathrm{d} ; \mathrm{p}<0.05 \\
\text { b vs. c; } \mathrm{p}<0.01, \mathrm{c} v s . \mathrm{d} ; \mathrm{p}<0.05\end{array}$ \\
\hline Methionine & $27.3 \pm 3.6$ & $25.4 \pm 3.7$ & $27.6 \pm 4.9$ & $20.6 \pm 3.3$ & $\begin{array}{l}\text { a } v s . \mathrm{d} ; \mathrm{p}<0.01, \mathrm{~b} v s . \mathrm{d} ; \mathrm{p}<0.01 \\
\text { c } v s . \mathrm{d} ; \mathrm{p}<0.01\end{array}$ \\
\hline Phenylalanine & $56.9 \pm 7.0$ & $54.2 \pm 5.5$ & $65.4 \pm 8.8$ & $51.9 \pm 6.0$ & $\begin{array}{l}\text { a vs. c; }<<0.01, \text { a } v s . \mathrm{d} ; \mathrm{p}<0.01 \\
\text { b vs. c; }<<0.01, \text { c } v s . \mathrm{d} ; \mathrm{p}<0.01\end{array}$ \\
\hline Threonine & $131.4 \pm 21.5$ & $133.5 \pm 43.9$ & $136.5 \pm 27.4$ & $121.8 \pm 41.9$ & No significance \\
\hline Tryptophan & $65.8 \pm 9.1$ & $65.4 \pm 7.1$ & $58.7 \pm 9.2$ & $51.4 \pm 6.4$ & $\begin{array}{l}\text { a vs. c; } \mathrm{p}<0.01, \text { a } v s . \mathrm{d} ; \mathrm{p}<0.01 \\
\text { b vs. c; } \mathrm{p}<0.05, \mathrm{~b} v s . \mathrm{d} ; \mathrm{p}<0.01 \\
\text { c vs. d; } \mathrm{p}<0.01\end{array}$ \\
\hline Isoleucine & $67.9 \pm 11.2$ & $56.6 \pm 7.9$ & $65.7 \pm 8.5$ & $49.9 \pm 7.4$ & $\begin{array}{l}\text { a } v s . \mathrm{b} ; \mathrm{p}<0.01, \text { a } v s . \mathrm{d} ; \mathrm{p}<0.01 \\
\text { b vs. c; }<<0.01, \mathrm{~b} v s . \mathrm{d} ; \mathrm{p}<0.05 \\
\text { c vs. } \mathrm{d} ; \mathrm{p}<0.01\end{array}$ \\
\hline Leucine & $129.8 \pm 16.3$ & $104.6 \pm 10.3$ & $133.8 \pm 17.5$ & $100.3 \pm 12.6$ & $\begin{array}{l}\text { a vs. b; }<<0.01, \text { a } v s . \mathrm{d} ; \mathrm{p}<0.01 \\
\text { b vs. c; }<<0.01, \text { c } v s . \mathrm{d} ; \mathrm{p}<0.01\end{array}$ \\
\hline Valine & $221.9 \pm 23.8$ & $203.9 \pm 25.1$ & $228.1 \pm 30.6$ & $186.5 \pm 32.4$ & $\begin{array}{l}\text { a } v s . \mathrm{d} ; \mathrm{p}<0.01, \mathrm{~b} v s . \mathrm{c} ; \mathrm{p}<0.05 \\
\text { c } v s . \mathrm{d} ; \mathrm{p}<0.01\end{array}$ \\
\hline Tyrosine & $58.2 \pm 8.7$ & $56.8 \pm 8.4$ & $70.3 \pm 12.0$ & $54.1 \pm 8.4$ & $\begin{array}{l}\text { a } v s . \mathrm{c} ; \mathrm{p}<0.01, \mathrm{~b} v s . \mathrm{c} ; \mathrm{p}<0.01 \\
\text { c } v s . \mathrm{d} ; \mathrm{p}<0.01\end{array}$ \\
\hline Alanine & $356.0 \pm 68.9$ & $346.1 \pm 82.3$ & $415.9 \pm 75.7$ & $326.1 \pm 64.4$ & $\begin{array}{l}\text { a vs. c; } \mathrm{p}<0.01, \mathrm{~b} \text { vs. c; } \mathrm{p}<0.01 \\
\text { c vs. d; }<<0.01\end{array}$ \\
\hline A-Amino Butyric Acid & $20.9 \pm 5.3$ & $19.0 \pm 6.1$ & $21.7 \pm 6.5$ & $17.9 \pm 4.1$ & c $v s . \mathrm{d} ; \mathrm{p}<0.01$ \\
\hline Arginine & $77.6 \pm 15.0$ & $65.4 \pm 14.1$ & $79.3 \pm 17.6$ & $82.4 \pm 17.5$ & $\begin{array}{l}\text { a vs. b; }<<0.05, \mathrm{~b} v s . \mathrm{c} ; \mathrm{p}<0.05 \\
\text { b vs. d; } \mathrm{p}<0.01\end{array}$ \\
\hline Asparagine & $45.0 \pm 6.1$ & $47.9 \pm 7.9$ & $47.3 \pm 5.7$ & $30.1 \pm 8 . .1$ & $\begin{array}{l}\text { a } v s . \mathrm{d} ; \mathrm{p}<0.01, \mathrm{~b} v s . \mathrm{d} ; \mathrm{p}<0.01 \\
\text { c } v s . \mathrm{d} ; \mathrm{p}<0.01\end{array}$ \\
\hline Aspartic Acid & $3.4 \pm 1.4$ & $2.5 \pm 0.4$ & $3.4 \pm 0.7$ & $9.7 \pm 2.5$ & $\begin{array}{l}\text { a } v s . \mathrm{d} ; \mathrm{p}<0.01, \mathrm{~b} v s . \mathrm{d} ; \mathrm{p}<0.01 \\
\text { c } v s . \mathrm{d} ; \mathrm{p}<0.01\end{array}$ \\
\hline Citrulline & $22.2 \pm 3.6$ & $23.2 \pm 4.0$ & $27.0 \pm 6.2$ & $35.8 \pm 8.5$ & $\begin{array}{l}\text { a vs. c; } \mathrm{p}<0.01, \text { a } v s . \mathrm{d} ; \mathrm{p}<0.01 \\
\text { b vs. } \mathrm{d} ; \mathrm{p}<0.01, \mathrm{c} v s . \mathrm{d} ; \mathrm{p}<0.01\end{array}$ \\
\hline Cystine & $14.1 \pm 4.1$ & $27.1 \pm 5.5$ & $23.6 \pm 6.7$ & $3.7 \pm 1.6$ & $\begin{array}{l}\text { a vs. b; } \mathrm{p}<0.01, \mathrm{a} v s . \mathrm{c} ; \mathrm{p}<0.01, \text { a vs. } \mathrm{d} ; \mathrm{p}<0.01, \mathrm{~b} \text { vs.c; } \\
\mathrm{p}<0.05, \mathrm{~b} \text { vs. d; } \mathrm{p}<0.01, \mathrm{c} v s . \mathrm{d} ; \mathrm{p}<0.01\end{array}$ \\
\hline Glutamic Acid & $37.0 \pm 11.6$ & $23.5 \pm 6.1$ & $45.0 \pm 16.5$ & $163.8 \pm 81.7$ & a $v s . \mathrm{d} ; \mathrm{p}<0.01, \mathrm{~b} v s . \mathrm{d} ; \mathrm{p}<0.01, \mathrm{c} v s . \mathrm{d} ; \mathrm{p}<0.01$ \\
\hline Glutamine & $548.5 \pm 64.0$ & $534.4 \pm 70.0$ & $575.6 \pm 52.0$ & $349.6 \pm 87.6$ & a $v s . \mathrm{d} ; \mathrm{p}<0.01, \mathrm{~b} v s . \mathrm{d} ; \mathrm{p}<0.01, \mathrm{c} v s . \mathrm{d} ; \mathrm{p}<0.01$ \\
\hline Glycine & $213.5 \pm 25.9$ & $217.3 \pm 56.8$ & $198.5 \pm 28.6$ & $236.7 \pm 65.3$ & c $v s . \mathrm{d} ; \mathrm{p}<0.05$ \\
\hline Mono Ethanolamine & $8.5 \pm 1.2$ & $7.0 \pm 0.9$ & $8.8 \pm 1.3$ & $7.6 \pm 1.0$ & 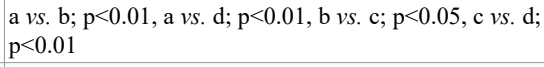 \\
\hline Ornithine & $59.4 \pm 12.5$ & $61.7 \pm 17.3$ & $72.5 \pm 13.9$ & $61.3 \pm 15.3$ & a vs. c; $\mathrm{p}<0.01, \mathrm{c} v s . \mathrm{d} ; \mathrm{p}<0.01$ \\
\hline Proline & $172.8 \pm 58.4$ & $139.9 \pm 40.7$ & $169.2 \pm 56.9$ & $116.7 \pm 39.5$ & a vs. d; $\mathrm{p}<0.01, \mathrm{c} v s . \mathrm{d} ; \mathrm{p}<0.01$ \\
\hline Serine & $124.6 \pm 17.1$ & $129.3 \pm 25.9$ & $105.5 \pm 18.2$ & $118.3 \pm 22.2$ & a vs. c; $;<0.01$, b vs. c; $\mathrm{p}<0.01$ \\
\hline Taurine & $49.9 \pm 1.5$ & $50.9 \pm 1.7$ & $67.7 \pm 3.1$ & $61.2 \pm 1.8$ & $\begin{array}{l}\text { a vs. c; } \mathrm{p}<0.01, \text { a } v s . \mathrm{d} ; \mathrm{p}<0.01, \mathrm{~b} v s . \mathrm{c} ; \mathrm{p}<0.01, \mathrm{~b} v s . \mathrm{d} ; \\
\mathrm{p}<0.01\end{array}$ \\
\hline Total Amino Acids & $2751.7 \pm 215.0$ & $2602.8 \pm 295.2$ & $2891.4 \pm 201.6$ & $2476.9 \pm 233.2$ & a vs. d; $\mathrm{p}<0.01, \mathrm{~b}$ vs. c; $\mathrm{p}<0.01, \mathrm{c} v s . \mathrm{d} ; \mathrm{p}<0.01$ \\
\hline $\begin{array}{l}\text { Total Essential Amino } \\
\text { Acids }\end{array}$ & $965.3 \pm 89.0$ & $871.6 \pm 84.1$ & $985.4 \pm 94.9$ & $824.8 \pm 92.9$ & $\begin{array}{l}\text { a vs. b; }<<0.01, \text { a vs. d; }<<0.01, \mathrm{~b} v s . \mathrm{c} ; \mathrm{p}<0.05 \text {, c vs. d; } \\
\mathrm{p}<0.01\end{array}$ \\
\hline $\begin{array}{l}\text { Total Non-Essential } \\
\text { Amino Acids }\end{array}$ & $1786.4 \pm 153.3$ & $1731.2 \pm 242.8$ & $1906.0 \pm 166.0$ & $1652.1 \pm 168.4$ & $\begin{array}{l}\text { a } v s . \mathrm{c} ; \mathrm{p}<0.05, \text { a } v s . \mathrm{d} ; \mathrm{p}<0.01, \mathrm{~b} v s . \mathrm{c} ; \mathrm{p}<0.01, \mathrm{c} v \text { s. } \mathrm{d} \\
\mathrm{p}<0.01\end{array}$ \\
\hline $\begin{array}{l}\text { Total Branched Chain } \\
\text { Amino Acids }\end{array}$ & $419.5 \pm 48.3$ & $365.1 \pm 38.9$ & $427.5 \pm 52.3$ & $336.8 \pm 49.2$ & $\begin{array}{l}\text { a vs. b; }<<0.01, \text { a } v s . d ; p<0.01, b \text { vs. c; } p<0.05, \text { c } v s . d ; \\
\text { p }<0.01\end{array}$ \\
\hline Fisher Ratio & $3.7 \pm 0.4$ & $3.3 \pm 0.5$ & $3.2 \pm 0.4$ & $3.2 \pm 0.4$ & a $v s$. b; $;<0.01$, a $v s . \mathrm{c} ; \mathrm{p}<0.01$, a $v s . \mathrm{d} ; \mathrm{p}<0.01$ \\
\hline
\end{tabular}


Table 3. Relationships between the uptakes of proteins obtained from various foods sources and plasma levels of amino acid

\begin{tabular}{|c|c|c|c|c|}
\hline \multicolumn{5}{|l|}{ Correlation coefficients } \\
\hline & Young men & $\begin{array}{c}\text { Young } \\
\text { women }\end{array}$ & Old men & Old women \\
\hline $\begin{array}{l}\text { Total protein uptake } v s . \text { Total } \\
\text { plasma amino acids levels }\end{array}$ & -0.14 & 0.17 & -0.26 & 0.21 \\
\hline $\begin{array}{l}\text { Animal protein uptake } v s \text {. Total } \\
\text { plasma amino acids levels }\end{array}$ & -0.17 & 0.08 & -0.21 & 0.16 \\
\hline $\begin{array}{l}\text { Vegetable protein uptakes vs, total } \\
\text { plasma amino acids levels }\end{array}$ & -0.02 & 0.24 & -0.32 & 0.22 \\
\hline $\begin{array}{l}\text { Bean uptake } v s \text {. Total plasma } \\
\text { amino acids levels }\end{array}$ & -0.2 & 0 & 0.07 & 0.24 \\
\hline $\begin{array}{l}\text { Fish uptake } v s \text {. Total plasma amino } \\
\text { acids levels }\end{array}$ & 0.12 & 0.08 & -0.18 & 0.27 \\
\hline $\begin{array}{l}\text { Meat uptake } v s . \text { Total plasma } \\
\text { amino acids levels }\end{array}$ & $-0.31^{*}$ & 0.19 & -0.15 & -0.24 \\
\hline $\begin{array}{l}\text { Egg uptake } v s \text {. Total plasma amino } \\
\text { acids levels }\end{array}$ & $-0.37^{* *}$ & -0.12 & -0.05 & -0.25 \\
\hline $\begin{array}{l}\text { Milk uptake } v s . \text { Total plasma } \\
\text { amino acids levels }\end{array}$ & 0.05 & -0.18 & -0.07 & 0.2 \\
\hline
\end{tabular}

"p $<0.01, " \mathrm{p}<0.05$

Table 4. Relationship between total protein uptake and various plasma factors

\begin{tabular}{|l|c|c|c|c|}
\hline Total protein uptake $\boldsymbol{v s .}$ & Young men & $\begin{array}{c}\text { Young } \\
\text { women }\end{array}$ & Old men & Old women \\
\hline Fasting glucose levels & 0.17 & 0.01 & -0.02 & -0.26 \\
\hline Plasma insulin levels & -0.18 & 0.06 & 0.12 & 0.06 \\
\hline Plasma TG levels & -0.06 & 0.07 & 0 & -0.09 \\
\hline Plasma HDL-cholesterol levels & $0.29^{*}$ & -0.04 & 0.09 & $0.33^{*}$ \\
\hline Plasma LDL-cholesterol levels & -0.18 & 0.14 & 0.03 & -0.26 \\
\hline
\end{tabular}

" $<<0.05$

Table 5. Correlation between BCAAs and plasma levels of various factors

\begin{tabular}{|l|c|c|c|c|}
\hline & $\begin{array}{c}\text { Young } \\
\text { men }\end{array}$ & $\begin{array}{c}\text { Young } \\
\text { women }\end{array}$ & Old men & $\begin{array}{c}\text { Old } \\
\text { women }\end{array}$ \\
\hline Valine $v s$. Plasma fasting glucose levels & 0.11 & -0.10 & -0.28 & 0.12 \\
\hline Valine $v s$. Plasma insulin levels & $0.63^{* *}$ & 0.22 & 0.22 & 0.19 \\
\hline Valine $v s$. HDL-Chol. & 0.00 & $0.44^{*}$ & -0.25 & 0.01 \\
\hline Valine $v$ s. LDL-Chol. & 0.18 & 0.24 & 0.18 & -0.04 \\
\hline Valine $v s$. TG & 0.24 & 0.21 & 0.34 & -0.17 \\
\hline Leucine vs .plasma fasting glucose levels & 0.09 & 0.06 & -0.07 & 0.15 \\
\hline Leucine $v s$. Plasma levels of insulin & $0.55^{* *}$ & 0.28 & 0.23 & 0.31 \\
\hline Leucine $v s$. HDL-Chol. & -0.03 & 0.28 & -0.26 & -0.11 \\
\hline Leucine $v s$. LDL-Chol. & 0.10 & 0.31 & 0.10 & 0.09 \\
\hline Leucine $v s$. TG & 0.16 & 0.31 & 0.27 & -0.11 \\
\hline Isoleucine $v s$. Plasma fasting glucose levels & 0.24 & 0.09 & -0.05 & 0.17 \\
\hline Isoleucine $v s$. Plasma insulin levels & $0.47^{* *}$ & 0.16 & 0.27 & 0.11 \\
\hline Isoleucine $v s$. HDL-Chol. & -0.05 & 0.38 & -0.26 & -0.04 \\
\hline Isoleucine $v s$. LDL-Chol. & 0.10 & 0.34 & -0.05 & 0.06 \\
\hline Isoleucine $v s$. TG & 0.13 & 0.14 & 0.36 & -0.19 \\
\hline
\end{tabular}

${ }^{* *} \mathrm{p}<0.01,{ }^{*} \mathrm{p}<0.05$

Thus it is quite natural that plasma levels of BCAAs increase in patients of type 2 diabetes [4-7] because the metabolism of such amino acids are impaired.

In the present studies we report that plasma levels of essential amino acids are lower in women than in men, and that their levels are lower in old people than in young people (Table 2). These results may mean that in healthy old men and women levels of BCAAs and EAAs are not high, thus indicating normal amino acids metabolism.

The uptakes of total, animal, and vegetable proteins did not increase total amino acids levels in the plasma (Table3), which may mean that the degradation and synthesis of amino acids are well regulated and not influenced by some extent of the increased uptake of proteins in healthy people.

It is also interesting that no correlations existed between protein uptakes and plasma insulin or glucose levels (Table 4). It is extremely interesting that increase in plasma levels of BCAAs increased plasma insulin levels (Table 5). These results indicate that although insulin levels are influenced by plasma levels of BCAAs, in healthy people the metabolism of BCAAs and their effects on glucose homeostasis are not impaired.

\section{Acknowledgment}

Experiments were designed and performed by all of the authors. AT wrote a manuscript. Statistical analyses were done by FS. All authors read the manuscript and approved the final version. All the authors had responsibilities for the final content. No conflicts of interest for any author.

\section{Financial support}

This study was supported by grants by Ito Memorial Foundation and NPO "International Projects on Food and Health".

\section{References}

1. Kolanu BR, Boddula V, Vadakedath S, Kandi V (2017) Amino Acid (Leucine) Chromatography: A Study of Branched-Chain Aminoaciduria in Type 2 Diabetes. Cureus 9: e1091. [Crossref]

2. Buse MG, Biggers JF, Friderici KH, Buse JF (1972) Oxidation of branched chain amino acids by isolated hearts and diaphragms of the rat. The effect of fatty acids, glucose, and pyruvate respiration. J Biol Chem 247: 8085-8096.

3. McCormack SE, Shaham O, McCarth MA, Deik AA, Wang TJ, et al. (2013) Circulating Branched-chain Amino Acid Concentrations Are Associated with Obesity and Future Insulin Resistance in Children and Adolescents. Pediatr Obes 8: 52-61. [Crossref]

4. Adeva MM, Calviño J, Souto G, Donapetry C (2012) Insulin resistance and the metabolism of branched-chain amino acids in humans. Amino Acids 43:171-81.

5. Giesbertz P, Daniel H (2016) Branched-chain amino acids as biomarkers in diabetes. Curr Opin Clin Nutr Metab 19: 48-54.

6. Okekunle AP, Li Y, Liu L, Du S, Wu X, et al. Abnormal circulating amino acid profiles in multiple metabolic disorders. Diabetes Res Clin Pract 132: 45-58. [Crossref]

7. Connelly MA, Wolak-Dinsmore J, Dullaart RPF (2017) Branched Chain Amino Acids Are Associated with Insulin Resistance Independent of Leptin and Adiponectin in Subjects with Varying Degrees of Glucose Tolerance. Metab Syndr Relat Disord 15: 183-186.

8. Shimizu F, Ishii Y, Ogawa M, Takao T, Matsuoka K, et al. (2017) Relationship between Various Food Uptakes and Body Mass Index (BMI) in Japanese Young and Old Men and Women. J Clin Nutr Diet 3: 2 .

9. Storrs C (2017) How poverty affects the brain. Nature 547: 150-152. [Crossref]

10. Stefanick ML (2017) Not just for men. Scientific American 317: 48-53.

11. Felig P (1975) Amino acid metabolism in man. Annu Rev Biochem 44: 933-955. [Crossref]

12. Jefferson LS, Li JB, Rannels SR (1977) Regulation by insulin of amino acid release and protein turnover in the perfused rat hemicorpus. J Biol Chem 252: 1476-1483. [Crossref]

13. Biolo G, Williams BD, Fleming RY, Wolfe RR (1999) Insulin action on muscle protein kinetics and amino acid transport during recovery after resistance exercise. Diabetes 48: 949-957

14. Robinson MM, Soop M, Sohn TS, Morse DM, Schimke JM, et al. (2014) High insulin combined with essential amino acids stimulates skeletal muscle mitochondrial protein synthesis while decreasing insulin sensitivity in healthy humans. Clin Endocrinol Metab 99: E2574-E2583.

15. Stancáková A, Civelek M, Saleem NK, Soininen P, Kangas AJ, et al. (2012) Hyperglycemia and a common variant of GCKR are associated with the levels of eight amino acids in 9,369 Finnish men. Diabetes 61: 1895-1902. 
16. Fernstrom JD, Wurtman RJ (1971) Brain serotonin content: increase following ingestion of carbohydrate diet. Science 174: 1023-1025.

17. Fernstrom JD, Wurtman RJ (1972) Brain serotonin content: physiological regulation by plasma neutral amino acids. Science 178: 414-416

18. Lipsett D, Madras BK, Wurtman RJ, Munro HN (1973) Serum tryptophan level after carbohydrate ingestion: selective decline in non-albumin-bound tryptophan coincident with reduction in serum free fatty acids. Life Sci II 12:57-64.
19. Pan RM, Mauron C, Glaeser B, Wurtman RJ (1982) Effect of various oral glucose doses on plasma neutral amino acid levels. Metabolism 31: 937-943.

20. Shimbo K1, Kubo S, Harada Y, Oonuki T, Yokokura T, et al. (2010) Automated precolumn derivatization system for analyzing physiological amino acids by liquid chromatography/mass spectrometry. Biomed Chromatogr 24: 683-691. [Crossref]

21. Ogawa M, Takao T, Ishii Y, Shimizu F, Takada A, et al. 2016. Changes in Plasma Amino Acid Levels After the Administration of Glucose or Sucrose to Healthy Young and Aged Males. M J Nutr 1: 008.

Copyright: $\odot 2017$ Shimizu F. This is an open-access article distributed under the terms of the Creative Commons Attribution License, which permits unrestricted use, distribution, and reproduction in any medium, provided the original author and source are credited. 